\title{
Studies of patents in biotechnological areas: empirical study on technological alerts to product development process and academic institutes
}

\author{
Eduardo Gomes Salgado, Fábio de Oliveira Neves \\ Federal University of Alfenas \\ e-mails: egsalgado@yahoo.com.br; eduardosalgado@unifal-mg.edu.br
}

\begin{abstract}
In Brazil only 50\% of research and development activities in the technological alert study (alert system on certain patents depositors for different themes) of stem cells, biodiesel, nanotechnology and nano-biotechnology are fulfilled within the country by individuals, public institutions and national companies. In biotechnology, an area of knowledge well closer to the basic research, it is expected even a greater participation of the public sector. This study aims to make a quantitative study of the areas mention above, linking the patent applications by Brazilian State, in addition to make a comparison between universities with biotechnology courses or related field with these companies, and companies which practice the product development process (PDP). The data was raised in 5 institutions. The universities were responsible for the largest number of patents between Jan. /2008 to Feb. /2010. In São Paulo State has concentrated the greatest number of patent applications, with 51\% of technological alert deposits. The Nanotechnology and Biodiesel patents predominated largely over others, reaching 51\% and 38\% respectively of the total deposits for the period and in the product development process.
\end{abstract}

Keywords: biotechnology; patent's deposits; technological alert; product development process.

\section{Introduction}

The concentration of research activities in Brazil are place in the most public and academic sectors, with a very small part into industrial participation, otherwise what happened in developed countries, where the high-tech research is found mainly in the industry (CRUZ, 2003; ASSAD, 2001; SILVA; DAGNINO, 2009). However, it is expected that this event reflects in the national industry appropriation, mainly if we consider that greatest part of the technological innovations were developed within it (CRUZ, 2003; SILVA; DAGNINO, 2009).

Commission of the $n$ European Communities (2002) designs, in report about the biotechnology development and implications of patent law, which this sector is one of the most promising in economic terms and in generating jobs (COMMISSION..., 2002; MAYERHOFF et al., 2007).

According to the Ministry of Science and Technology (BRASIL, 2012) biotechnology competition in Brazil appeared in the 80 's, and has been growing in the country thanks to the incentives of investment policies of the Federal Government, and it is regarded as one of the most promising areas, so that, if it was created a specific industrial sector policy: the biotechnology development policy, following the bio-safety and bio-ethics standards, a modern milestone, with a total of 5 laws, with emphasis on the productive development policy (PDP) that offers wide range of innovation.

Thereby, the community has mobilized to achieve the maximum benefit from resources, and between the measures supplemented is the regulatory milestone, that is able to give timing to the innovation and risky investments, including a range of Industrial property protection in the Community (MAYERHOFF et al., 2007).

According to Mayerhoff et al. (2007), the developed countries, when compared to the others, they have less restriction on the biotechnology legislation area, being the less restrictive the European Community. Many of the restrictions were due to the ethical issues, such as the stem cells. Some European countries adopt the definitions about this issue to specify the criteria for patentability.

As it regards the protection of intellectual property in biotechnological industries in Brazil, according to the Biominas Foundation (FUNDAÇÃO..., 2009), 43.7\% these industries said that they have deposited at least 1 (one) patent application at the National Institute of Industrial Property (INPI), with $37 \%$ of them have already had the patent granted. The high index of companies that do not 
have patents can be attributed to several factors, such as: low intellectual property mechanisms understanding and its importance, legislation, low innovative activity and high level of outsourcing companies (33\%), which have the lowest patenting activity in the industrial business (FUNDAÇÃO..., 2009).

In the public institutions where you can find the largest number of biotechnology professionals, also we can find the majority of patents. The predominance of the universities in patenting has a disadvantage that these institutions do not work into the commercial sector (FIGUEIREDO, PENTEADO; MEDEIROS, 2006).

The goal of this study is to evaluate quantitatively the participation of main States in deposition at the National Institute of Industrial Property (INPI) in biotechnology patents, relating to the biodiesel areas, stem cells, nanotechnology and nanobiotechnology, promoting comparison between companies that is engaged in the product development process (PDP) and academic institutions that have courses or any similar areas to the biotechnology in Brazil. This study was based on semiannual records which are called itself as technological alert produced by the Coordination of Studies and Programs (CEPRO) the institute is subordinated to the Information Dissemination Technology Center (CEDIN) subordinated by the Board of Directors of the Development Cooperation (DICOD), structured linked by the National Institute of Industrial Property (INPI, 2010).

It was used bibliographical research, which, according to Moresi (2003), it is regarded to a developed systematic study, based on material published in books, magazines, newspapers, networks, i.e. accessible material to the general public. Provides an analytical instrumental for any other kind of search, but can also run out by itself.

\section{Literature review}

\subsection{An overall view of biotechnology}

For Audrestsch (2001) and Samaan et al. (2012), biotechnology is a group of techniques and technologies that apply the genetics principles, immunology, genetic engineering, molecular and cell biology for the discovery of new products.

As Standing; Standing; Lin (2008) bio-economy means a set of activities that involve the biotech industry, goods and services needed for the supply and maintenance of this sector, whose importance is increasing rapidly in relation to the overall economy, since currently, one third of the world's gross domestic product is generated by Bio-industries

The biotech industry is an example of the supported industry in scientific knowledge (FINKEL, 1999). According to Ernst; Young (2010), it is an emerging industry, which has been growing rapidly in recent years, although it has passed, in the United States, in the period of 2007 to 2008 , by a decline in profits of $9 \%$ approximately, (It was from US\$ 86.8 billion of revenue for a total turnover of US $\$ 79.1$ billion) due to the global recession/global crisis.

The biotechnology sector covers a wide range of companies, with differences that refer to a number of common features: resources, product, competitive environment, innovation /entrepreneurship, market access, economical and political power. Most of them, in general, can be classified as small and medium businesses (DAS; HE, 2006).

The activities necessary to the product development process in biotechnology require large financial resources to maintain a search location for product development. By the fact, to be dealing with technologies of great scientific knowledge, where we can have high costs for the maintenance of the studies, for example, the performance assessment (CUNHA; MELO, 2006).

So for these companies being so competitive, they require multiple professionals, as well as alliances with other research centers for knowledge exchange between sectors (TEECE; PISANO; SHUEM, 1997). The performance of biotech companies depends on, in summary, investment in gifted and skilled human beings capital and its development in the ability of collaboration (LAHAM; TZABBAR; AMBURGEY, 2011).

According to Figueirado, Penteado and Medeiros (2006) Brazil is far away from the other developed countries in relation to the Organization of its system of biotechnology innovation, being the main obstacles to rectify the sector: regulation, start-up companies financing and investors' aversion about the patents issue.

In 2007 the Biominas Foundation held a national research with biotech companies. The report indicated 181 bioscience companies, forming the biotech sector were 71 . In 2009, another report fulfilled by Biominas showed a growth of $40 \%$, so the total number of bioscience companies was 253 and biotechnology, 91 (FUNDAÇÃO..., 2009).

The latest ones were distributed in seven branches: human and animal health, agriculture, environment, bioenergy, mixed and raw materials. In this way, according to Biominas (2007), many companies invest and have projects in biotechnology, but this is not its main activity and, therefore, is not considered biotechnology companies.

The Bioscience companies, in turn, are related to the human and animal health areas, agriculture and environment, as shown in Figure 1. Then, you need to consider that every

Bioscience company is a Biotech company, but not every company of Bioscience is a Biotech company

The last sector diagnosis by Biominas Foundation, published in 2009, focused its analysis on the biotech companies set by the Organization for economic cooperation and development (OECD), such as companies whose main 


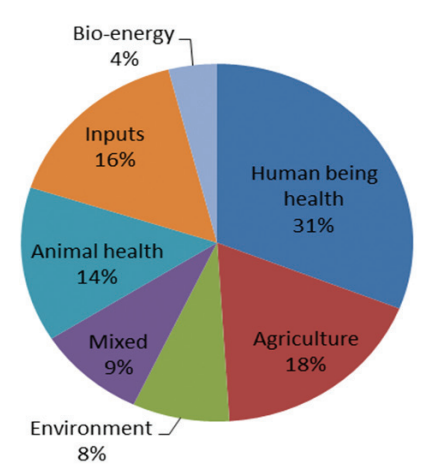

Figure 1. Percentage of biotechnology companies by field of study. Source: Adapted by Biominas (2009).

business activity involves the application of advanced biotechnology techniques for the production of goods and services or to conduct research and development (R\&D).

The concept of Biosciences was adopted, because it allows including, in the analysis, segments with increasing importance in Brazil, such as validation of new medicines (pre-clinical tests and clinical trials) and the development of next-generation medical devices that do not fit within the strict definition of biotechnology (FUNDAÇÃO..., 2009).

According to Corrêa (2000), the biotechnology has for the developing countries a huge potential for generating new opportunities in industry and trade. Nevertheless, for this potential to materialize is needed the support of both public and private initiative. In this way, the system of intellectual property (IP) becomes an instrument to achieve the development. The IP law scheme tends to be tied with the other policies and institutions, which, consequently, they are going to be engaged with the growth and development of the country (DUTFIELD, 2003).

So, there is a debate to achieve greater resources to the economic development of the sector, so that, the biotechnology suits to the intellectual protection. Thereby, this questioning is being done by proposals and projects for reconciliation of changes in Intellectual property laws within biotechnology. Another relevant consideration in relation to the patenting of biotechnology in developing countries refers to the natural resources and cultural knowledge. These cases relate to orders that have prior authorization or to those which use a project coming from a traditional knowledge. These are the central points of the discussion at the adequate patent protection (HAMILTON, 2006).

\subsection{Intellectual property}

According to WIPO (WORLD.., 2009) intellectual property (IP) refers to the mind creations: inventions, literary and artistic works, symbols, names, images and designs used in the business. The PI is divided into two categories: the first refers to industrial property, which includes inventions (patents), trademarks, industrial designs and geographical indications of origin which refers to copyright, literary and artistic works. The second refers to related rights which include those of performing artists in their performances, phonograms producers in their recordings into radio and broadcastings stations.

It is worth reminding that, according to Oliveira et al. (2005), a large part of information technology provides annually in the world and it is spread only in patent documents, so that the search in patent databases is essential to the scientific and technological development of the country and companies.

For Ferreira; Guimarães and Contador (2009) Brazilian companies, faced a globalized, competitive and market filled with technological innovations, has not attempted for the importance of using the patents as a competitive instrument, and of their exploitation as a source of technological information. The inhibitor factor more relevant to demonstrate that using patents as a source of technological information is the lack of culture in relation to the research on patented technology.

\subsection{Product development process}

The product development process (PDP) can be defined as the process by which a product is designed, engineered and launched in the market (FORMOSO, TZORTZOPOULOS; LIEDTKE, 2002). This process identifies customers' desires that are translated into specifications to be developed to generate business and technical solutions (SALGADO, SALOMON and MELLO, 2012; SILVA et al. 2013).

Cunha (2008) reports that, with the competitiveness increase among companies, the market focus becomes a priority, once the customer image appears as a central element in the development of the products, which it has to be differentiated in relation to its competitors on the market and features valued by consumers for increased chances of success.

According to Jun; Suh (2008), the product development process (PDP), when compared to the others, such as manufacturing, is complex and not organized, with evolutionary, iterative, uncertain and cooperatives. Therefore, if there is a wish to have an effective and efficient control of the PDP, it is necessary to describe the activities of stage in relation to the process' logic, which requires a modeling framework to capture the specific features of each company.

\section{Data analysis}

The first step in preparing this study was the definition of patent databases that would be used, in which whose data are deposited in Brazil in relation to biotechnology. The four bases used to analysis were stem cells, biodiesel, nanotechnology and nanobiotechnology. For the remaining 
areas of biotechnology such as agriculture and environment, they were not found a specific data, which limits the work. The INPI Brazilian base of patent, available in the integrated system of Industrial property (SINPI), contains the data of patent applications filed in Brazil.

After completing the search in the INPI, it was moved to the next step which consisted in the creation of a database of patent applications raised. After this block, they were again separated the patents in the years in which they were established and their own state.

After that they were separated only data that could be used as a platform for the study, they were not being used as patents made by individuals and those made in Brazil by international institutions. The patents and individuals which came from overseas were exempted, because the first is not focus of the current study and the last by the impossibility to characterize the location of the patent.

According from the data collect in the INPI (2010), there were a total of 518 requests for patents, but the great majority of patents requested in Brazil comes from overseas, in a total of 259 , followed by public institution a total of 112, by national companies 81 and individuals 66. Consequently, the intellectual property issue should be spread more in Brazil.

As we could see in Figure 2, data collected in the INPI, only $35 \%$ of the data concerning adding the public institution and national companies could be analyzed.

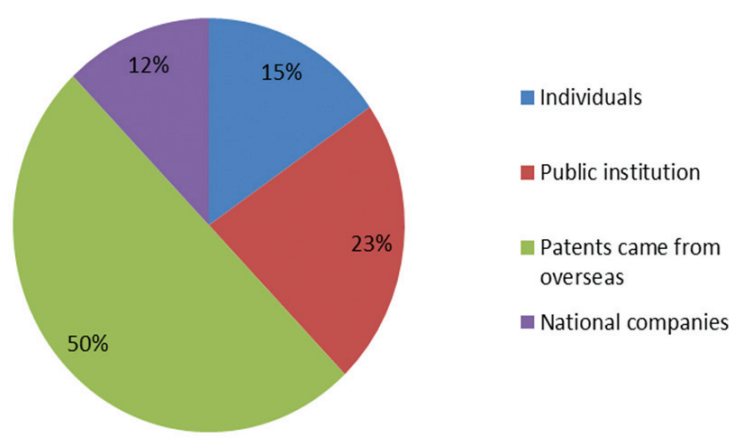

Figure 2. Percentage of different patents depositories of the technological alert study Source. Source: Done by the Author.
The next step was characterized by harmonization of patent applications from the names of the depositors, standardizing the writing o the searched base. It is important to note that, in the occurrence of strategic alliances, some companies listed as depositors belong to the same corporate group. For these cases were kept the depositors names that appeared in patent applications

Completed the steps, got as a result, a data set for the 94 patent applications of the topic: technological alert, deposited in Brazil, about technologies for stem cells, nanotechnology and nanobiotechnology, biodiesel, in the period from Dec. 2008 to Feb. 2010, as indicated in Table 1, the data collected in the INPI. During periods in which there were no studies for some subjects used the acronym WS (Without Study)

Figure 3: Shows the data collected in the INPI, a fluctuation between 11 to 17 patents during the period studied, with only lapse in the semester of Feb/2009, where the quantity of patents scored a total of 26 applications for deposit.

It is possible that in the studied semesters the national participation in relation to these types of patents has been maintained with small fluctuations due to the boards of technology management and intellectual property in several research institutions of national public sector.

When it is evaluated the States distribution patents, Figure 4, the data collected in the INPI, it can be notice that

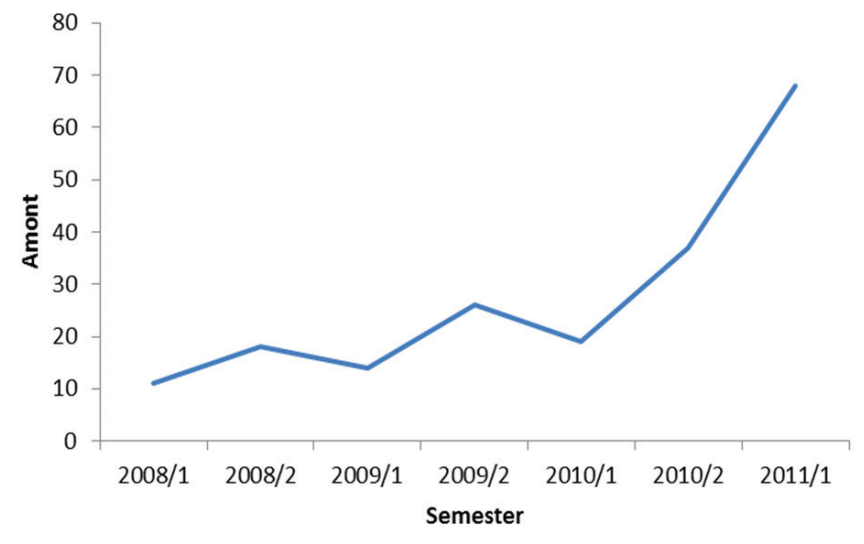

Figure 3. In relation to the quantity of patents covering the semester of the patents deposit. Source: Done by the Author.

Table 1. Qualitative research covering the semesters from Jan. /2008 to Feb. 20120 in relation to studied issue.

\begin{tabular}{|c|c|c|c|c|c|c|c|}
\hline & \multicolumn{6}{|c|}{ Quantity } & \multirow{2}{*}{$\begin{array}{c}\text { Total } \\
2\end{array}$} \\
\hline Stem cells & 1 & 0 & 0 & 1 & 0 & WS & \\
\hline Biodiesel & 10 & 1 & 13 & 9 & 3 & WS & 36 \\
\hline Nanotechnology & WS & 15 & 0 & 12 & 7 & 15 & 49 \\
\hline Nanobiotechnology & WS & 2 & 1 & 4 & WS & WS & 7 \\
\hline Year & Jan/2008 & $\mathrm{Feb} / 2008$ & Jan/2009 & $\mathrm{Feb} / 2009$ & Jan/2010 & $\mathrm{Feb} / 2010$ & 94 \\
\hline
\end{tabular}

Source: Done by the Author. 
the distribution is, mainly, from South /South-east line, with a large predominance of the State of São Paulo.

If it is divided in public and private deposits, we can have an overall view done by Figure 5, the data collected in the INPI. So, considering the public sector, it can reach 53 patents, it means $56 \%$ of the total. On the other hand

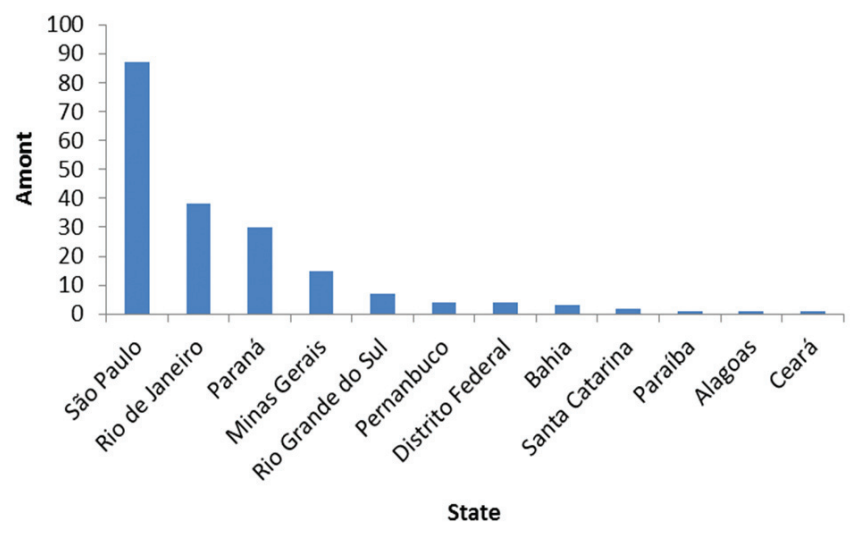

Figure 4. Quantity of patents in the States. Source: Done by the Author.

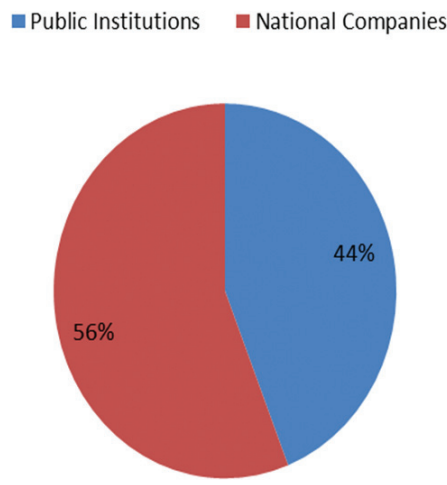

Figure 5. Public and private sector participation, from patents related to the technology alert study for the areas studied. Source: Done by the Author.

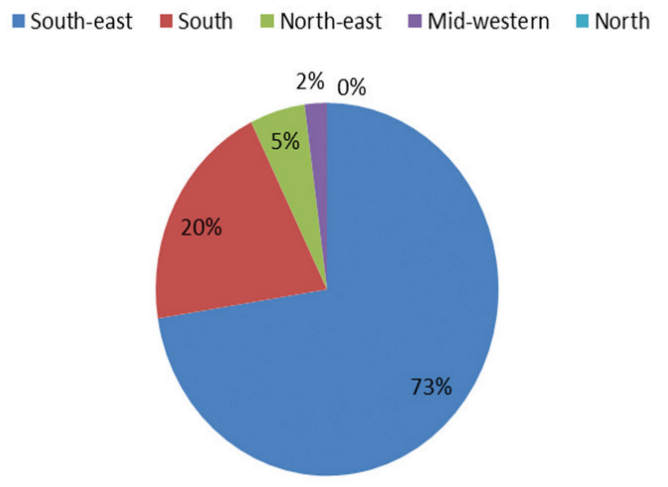

Figure 6. Concentration of patents by Brazilians regions. Source: Done by the Author. private companies have placed national patent applications, in a total of 41 , which represents $44 \%$ of the total.

In Figure 6, the data collected in the INPI, showed a profile of depositors. We can notice that the University sector is the largest depositor of patents in the studied areas, compared to national companies that have patents in these areas in the period of the study, differently that what occurs in other countries as the U.S.A, whose universities have $5 \%$ of the requested patents in the country (SILVA; DAGNINO, 2009)

Over the studies raised by Velho and Oliveira (2009); Asumpção (2000) were found that most of the patents concentrations are in academic business and is located in the South/South-east line. See the Figures: 4-6.

In Figure 7, data collected in the INPI, showed the depositors profile. We can notice that the University sector is the largest depositor of patents in the studied areas compared to national companies that have patents in these areas in the period of the study, differently that what occurs in other countries such as the U.S.A, whose universities have 5\% patents requested in the country (SILVA; DAGNINO, 2009)

Cruz (2003) showed that there is a great concentration of doctors in Brazilian universities in relation to industry. In addition, internationally the biotech is a field of University participation pretty well above the average courses. Patents for biotechnological area rely heavily on information obtained by basic research, justifying the higher participation of the academic sectors in the development of new technologies.

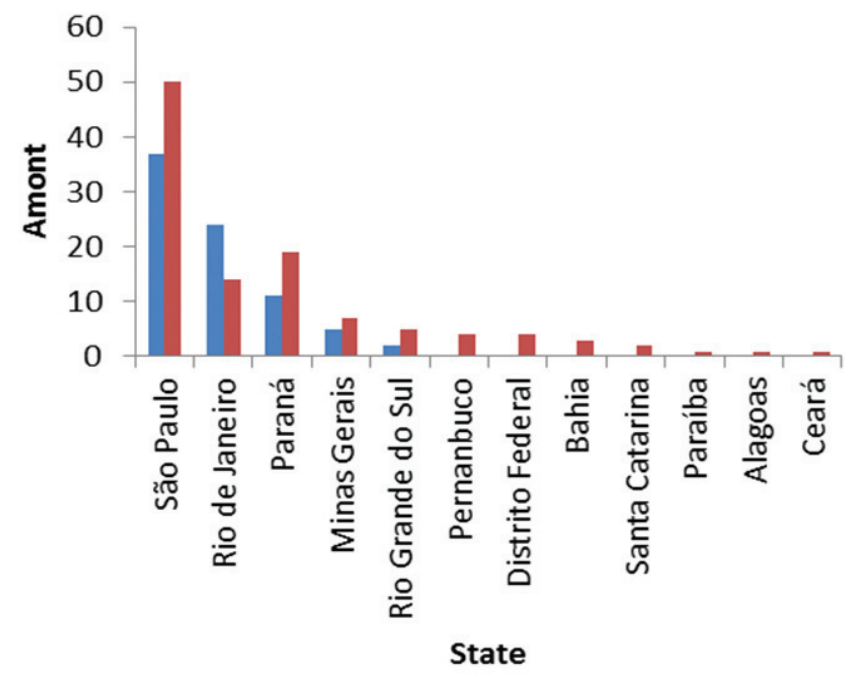

\section{national companies \\ Publics Institutions}

Figure 7. Comparison of public and private institutions in relation to the quantity of patents in technological alert for areas studied. Source: Done by the Author. 
Another important point when comparing Brazilian universities (public and private), as shown in Figure 8, by data collected in the Ministry of education (MEC), there is a great concentration of courses in Minas Gerais. However, the State is only the fourth in the ranking of this study. The State of São Paulo, is firstly in relation to filing patents, has only $9 \%$ of biotechnology or related areas, possibly because the high concentration of institutions with intellectual management property and the transfer of technology is found in the State of São Paulo in Brazil.

In Figure 9, analyzing separately the States which contains the post-graduation Strico e Lato Sensu courses in biotechnology or similar areas noted that there was no change when compared with the Figure 8, regarding the State classification; having only a slight difference in the percentages of quantities of courses by State.

Patent applications in the Brazilian States occur essentially Figures: 4, 6-9, by political force: academic investment and production. The rank of universities are: São Paulo universities, UNICAMP, USP, UNESP; Rio de Janeiro, UFRJ and UFF; Paraná: UFPR the only institution

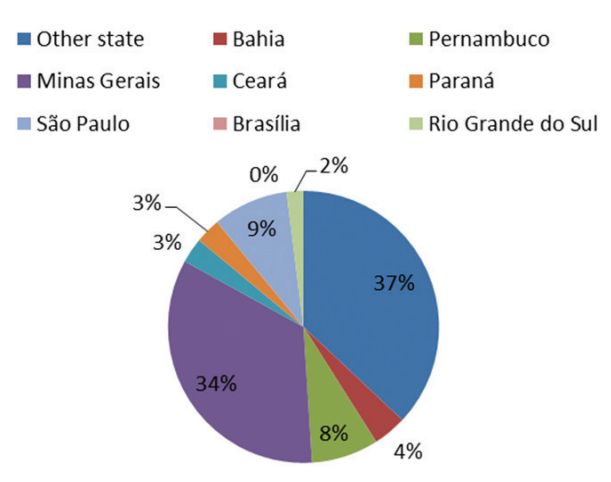

Figure 8. Percentage of Brazilian universities that with the biotechnology course or related areas. Source: Done by the Author.

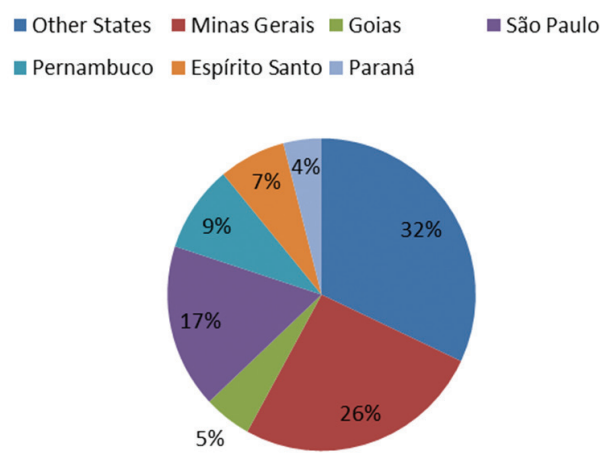

Figure 9. Percentage of post-graduating courses by State in biotechnology or similar area. Source: Done by the Author. to formalize requests for patents: UFMG, UFOP and UFLA; For the following States: Rio Grande do Sul, Santa Catarina, Distrito Federal and North-easterners: UFRGS, UFSC, UNB, UFBA, UFC, UFAL, UFPE, UFPA.

In Figure 9 it was raided companies in institutions in which files there are websites from those institutions: Biominas Foundation, ABIFINA (Brazilian Association Industries of chemicals and biotechnology and their specialties); SBBIOTEC (Brazilian society of Biotechnology); APL (Biotechnology network of bio-industry); Biorio (Biotech Center of Rio de Janeiro); CIETEC (Center of Innovation, entrepreneurship and technology); APL and CBNA (Brazilian College of Animal nutrition).

There was a total of 207 companies searched, being $38 \%$ in the State of São Paulo, $17 \%$ in Rio de Janeiro, the States with largest number of biotechnology companies. The comparison of Figure 8 with Figure 10 shows that, although the State of São Paulo has 9\% biotechnology related universities, it holds $38 \%$ of companies, while Minas Gerais, with $2.6 \%$ of biotech companies, takes the first position, with $34 \%$ universities in the State. Rio de Janeiro, although neither appear in Figure 8, ranks the second position in relation to companies in the State, a fact to be considered, mainly because there is several incubated companies in Bio-Rio.

As Castro (2001), during the Decade of 1990, with the opening up of trade and inflation control, companies sought new positions in relation to competitiveness. However, as the Brazilian industry was in a serious retrocession in relation the the world industry sought to shorten the delay with adoption of modern management. Summarazing, as the reaction should be fast and agile, the results in R\&D had uncertainty features and that took time to affect the productivity. In other way Brazilian universities have growth related to patenting from the second half of the 90's.

In the companies survey with features of the product development process, as shown in Figure 11, from the 228 national biotechnology companies raised by the study

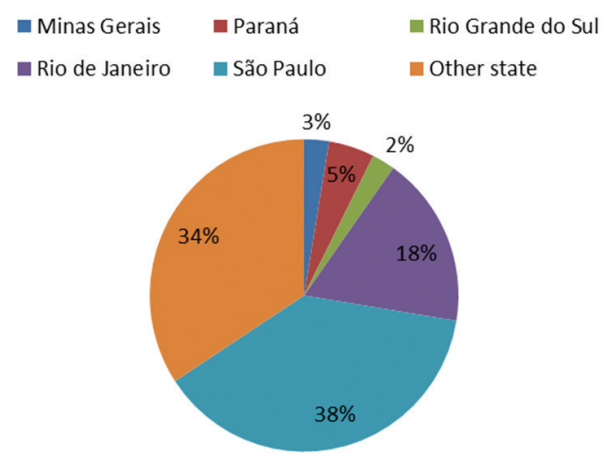

Figure 10. Percentage of biotechnology companies by State. Source: Done by the Author. 
platforms, 97 of them participate in the industry, totaling $42.54 \%$ approximately. This is due to the fact of PDP form in a transformation vehicle for conversion of a new product, through the adaptation of the model already worn or even by creating a new product. But the biotechnology is an area of basic research in which many processes are restricted to own labs, so that they ue use qualitative techniques such as monitoring.

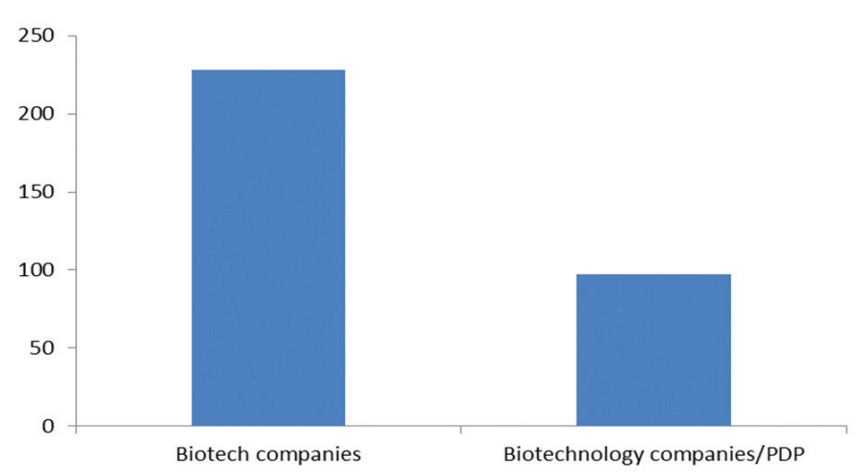

Figure 11. Biotech Companies versus biotechnology companies with PDP. Source: Done by the Author.

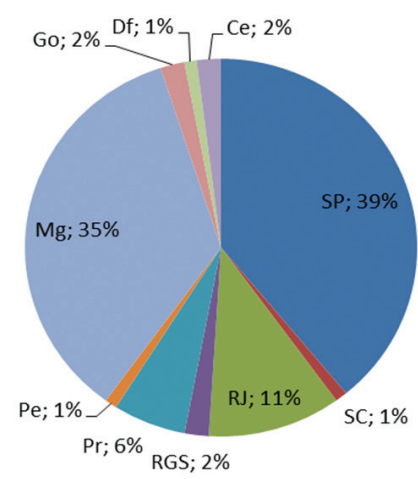

Figure 12. Concentration of biotech companies that use the PDP by State. Source: Done by the Author.

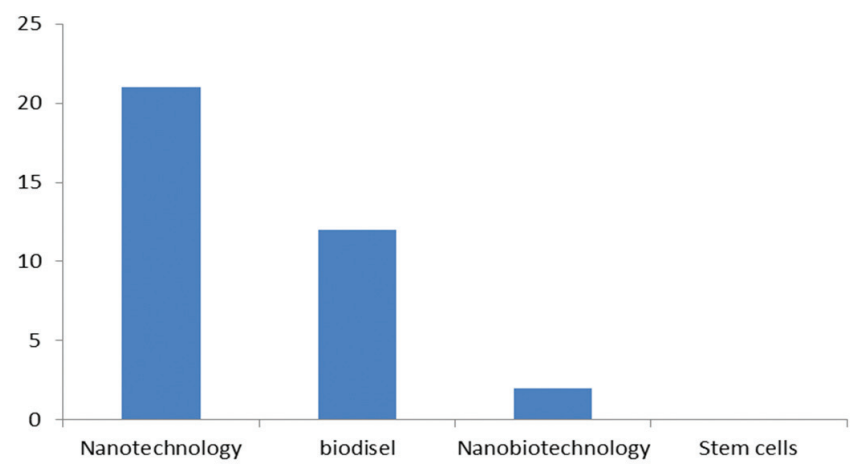

Figure 13. Product development process for areas in the technological alert. Source: Done by the Author.
Noticing at the Figure 12, made by a database analysis from the institutes shown in Figure 10, shows that the State with the largest production of new objects focused on biotechnology was São Paulo, followed by Minas Gerais and Rio de Janeiro, as shown also in Figures 7 and 10. In those States that concentrate the largest investments we can find companies with more new biotechnological products.

As at Figure 13 shows concurrently that companies that produce new objects and those that are placed on that proposed areas by technology alerts for biotechnology. Nanotechnology, followed by biofuels and then by nanobiotechnology were the areas in the technology alert which most used the PDP. Thanks by the fact of being large areas of insvestiments, mainly in the pharmaceutical industry, for which the nanotechnology dedicated to. As the biofuels, had a development with the ethanol production and sustainable technologies for this sector.

\section{Conclusion}

The numbers of patent applications by national universities and research institutes reflect the low culture of intellectual property protection, especially in the academic environment, where the notion that the new knowledge should be propagated and interchanged. The academic research is characterized by research freedom and by the flow of information. Without the goal of profit with the projects. On the other hand, the business activity that emphasizes in getting profits, the price of the products and the maintenance of secrecy around technological and commercial activities.

Regarding to the research and development activities, fulfilled mainly by the Brazilian public sector, it was expected even great participation in this sector in basic research. Among the public institutions, the universities were responsible for the largest number of deposits in the period, exceeding a participation of more than $56 \%$.

With a great number of doctors and national companies are concentrated in the South/South-east line, it was expected that the majority of patents were located in those States. But what is observed mainly in relation to the State of Minas Gerais, is that although having 34\% of biotechnology universities or similar area has only $6 \%$ of patent applications in the period from Jan/2008 to Feb/2010.

In relation to multinational companies deserve a great attention is Petrobrás, which did the majority of the patents in the State of Rio de Janeiro, escaping from the other Member States analysis, in that the most patents came from public institutions, backed to the biodiesel area.

In respect to the product development process, the area of greater highlighting was the nanotechnology, because at that time there was a large decline of patent medicines and biodiesel by-products, the second area of emphasis in the industry. The fact that the States are the largest quantities 
of concentrated enterprises, also the universities due to the largest financial investments and industry researchers.

The universities cultural aspects such as the rapid results dissemination may be affected if the researcher prefers not to spread quickly its publication until completion of the patent application. At the other end, industry criticizes the universities with an argument that pay taxes, finance researches and have to pay to have access to them, mainly the ones focused on biotechnology, which holds the majority of national patents.

However, despite all the difficulties, it is expected that the number of national patents in these areas would grow in the coming years, mainly in the States with the largest amount of public universities and multinational companies, where over these locations are the professionals in these areas.

For a greater homogenization between the States it is necessary to invest in basic research into the public universities, mainly the ones with doctor's courses training. And more, the need of the licensing agreement for these technologies for its effective use.

\section{References}

ASSAD, A. Programa Nacional de Biotecnologia e Recursos Genéticos. Brasília: Ministério da Ciência e Tecnologia, 2001. (Documento para consulta pública).

ASUMPÇÃO, E. G. A utilização do sistema de patentes pelas universidades brasileiras nos anos 90. Rio de Janeiro: INPI, 2000.

AUDRESTSCH, D. B. The Role of Small Firms in U.S. Biotechnology Clusters. Small Business Economics, v. 17, n. 1- 2, p. 3-15, 2001. http://dx.doi. org/10,1023/A:1011140014334

BIOMINAS. Fundação, Estudo de Empresa de Biotecnologia do Brasil, Brasil, 2007.

BRASIL. Ministério da Ciência e Tecnologia. Apresentação biotecnologia. Disponível em: <http://www.mct.gov.br/ index.php/content/view/3546.html>. Acesso em: mar. 2012.

CASTRO, A. B. A reestruturação industrial brasileira nos anos 90: uma interpretação. Revista de Economia Política, v. 21, n. 3, p. 3-26, 2001.

COMMISSION OF THE EUROPEAN COMMUNITIES Life Sciences and Biotechnology: a strategy for Europe 2002. Disponível em: <http://ec.europa.eu/biotechnology/pdf/ com2002-27_en.pdf>. Acesso em: mar. 2011.

CORRÊA, C. M. Reviewing the TRIPS Agreement. In: UNITED NATIONS CONFERENCE ON TRANDE AND DEVELOPMENT - UNCTAD. Positive Trade Agenda For Developing Countries: Issues for future Trade Negotiations. Geneva: UCTAD, 2000. p. 1-508.
CRUZ, B. H. C. A universidade, a empresa e a pesquisa que o país precisa. Cadernos de Estudos Avançados, v. 1, n. 1, p. 5-22, 2003.

CUNHA, C. R.; MELO, M. C. O. A Confiança nos Relacionamentos Interorganizacionais: O Campo da Biotecnologia em Análise. RAE-eletrônica, v. 5, n. 2, p.1-26, 2006. http://dx.doi.org/10.1590/S167656482006000200009

CUNHA, G. B. A Evolução dos Modos de Gestão do Desenvolvimento de Produtos. Produtos e Produção, v. 9, n. 2, p. 71-90, 2008.

DAS, T. K.; HE, I. Y. Entrepreneurial firms in search of established partners: review and recommendations. International Journal of Entrepreneurial Behaviour and Research, v. 12, n. 3, p.114-143, 2006. http://dx.doi. org/10.1108/13552550610667422

DUTFIELD, G. Intelectual Property Rights and Development. Genebra: UNCTAD/ICTSD, 2003. Disponível em: <http:// www.planalto.gov.br/ccivil_03/_Ato2004 2006/2005/Lei/ L11105.htm>. Acesso em: mar. 2011.

ERNST and YOUNG. The economic contributions of the biotechnology industry to the U.S. economy. Prepared for the Biotechnology Industry Organization by Ernst \& Young economics. 2010. Disponível em: <http:// www.bio.org>. Acesso em: mar. 2011.

FERREIRA, A. A.; GUIMARÃES, E. R.; CONTADOR, J. C. Patente como instrumento competitivo e como fonte de informação tecnológica. Gestão e Produção, v. 12, n. 2, p. 209-221, 2009.

FIGUEIREDO, L. G. M.; PENTEADO, M. I. O.; MEDEIROS, P. T. Patenteamento em biotecnologia agropecuária: cenário brasileiro. Biotecnologia Ciência e Desenvolvimento, v. 9 , n. 36, p.32-39, 2006.

FINKEL, E. Budget backs report on boosting biotech. Science, v. 284, n. 5418, p.1248-1249, 1999. http://dx.doi. org/10.1126/science.284.5418.1248

FORMOSO, C. T.; TZORTZOPOULOS, P.; LIEDTKE, R. A model for managing the product development process in house. Engineering Construction and Architectural Management, v. 9, n. 5 p.419-432, 2002. http://dx.doi. org/10.1046/j.1365-232X.2002.00274.x

FUNDAÇÃO BIOMINAS. Estudo das empresas de Biociências. 2009. p. 1-26.

HAMILTON, C. Editorial Intellectual property rights and living organisms. International Journal of Surgery, v. 4, n. 3, p.82-85, 2006. http://dx.doi.org/10.1111/ j.14718847.2006.00168.x

INSTITUTO NACIONAL DE PROPRIEDADE INDUSTRIAL - INPI. Propriedade Intelectual. Disponível 
em: <http://www.inpi.gov.br/legislacao/propriedade. htm?tr1>. Acesso em: abr. 2010.

JUN, H. B.; SUH, H. W. A Modeling Framework for Product Development Process Considering its Characteristics. IEEE Transactions on engineering management, v. 55, n. 1, p. 103-119, 2008. http://dx.doi.org/10.1109/ tem. 2007.912808

LAHAM, A. A.; TZABBAR.; AMBURGEY, T. L. The dynamics of knowledge stocks and knowledge flows: innovation consequences of recruitment and collaboration in biotech. Industrial and Corporate Change, v. 20, n. 2, p.1-29, 2011. http://dx.doi.org/10.1093/icc/dtr001

MAYERHOFF, Z. D. V. L. et al. Estudo Comparativo dos Critérios de Patenteabilidade para Invenções Biotecnológicas em Diferentes Países. Grupo de Trabalho Especial em Biotecnologia, Instituto Nacional de Propriedade Industrial (INPI), Diretoria de Articulação - Dart Centro, Documentação e Informação Tecnológica - Cedin Divisão de Estudos e Programas- Diespro, 2007. p. 1-88.

MORESI, E. Metodologia de Pesquisa. 2003. Dissertação (Mestrado em Gestão de Conhecimento e Tecnologia de Informação)-Universidade Católica de Brasília, Brasília, 2003.

OLIVEIRA, L. G.; SUSTER, R.; PINTO A. C.; RIBEIRO, N. M.; SILVA, R. B. Informações de patentes: ferramenta indispensável para a pesquisa e o desenvolvimento tecnológico. Química Nova, v. 28, p. 36-40, 2005. Suplemento. http://dx.doi.org/10.1590/S010040422005000700007x

SAlGADO, E. G.; SALOMON, V. A. P.; MELLO, C. H. P. Analytic hierarchy prioritisation of new product development activities for electronics manufacturing.
International Journal of Production Research, v. 50, n. 17, p. 4860-4866, 2012. http://dx.doi.org/10.1080/002075 43.2012 .657972

SAMAAN, M. et al. Identificação dos fatores críticos de sucesso no desenvolvimento de produtos de empresas de biotecnologia do estado de Minas Gerais. Revista Produção, v. 22, p. 436-447, 2012.

SILVA, R. B.; DAGNINO, R. Universidades públicas brasileiras produzem mais patentes que empresas: isso deve ser comemorado?. Economia e Tecnologia, v. 17, n. 5, p. $115-118,2009$.

SILVA, C. E. S. et al. Integration of computer simulation in design for manufacturing and assembly. International Journal of Production Research, p. 1-16, 2013. http:// dx.doi.org/10.1080/00207543.2013.853887

STANDING, S.; STANDING, C.; LIN, C. A Framework for Managing, Knowledge in Strategic Alliances in the Biotechnology Sector. Systems Research and Behavioral Science, v. 25, n. 6, p.783-796, 2008. http://dx.doi. org/10.1002/sres.861

TEECE, D. J.; PISANO, G., SHUEM, A. Dynamic capabilities and strategic management. Strategic Management Journal, v. 18, n. 7, p. 509-533, 1997. http://dx.doi. org/10.1142/9789812834478_0002

VELHO, L. M. L; OLIVEIRA, R.M. Patentes acadêmicas no Brasil: uma análise sobre as universidades públicas paulistas e seus inventores. Parceria estratégica, v. 14, n. 29, p. 173-200, 2009.

W ORLD IN T ELLECT UAL PROPERT Y INDICATORS - WIPO. World intellectual property indicators. 2009. Disponível em: <http://www.wipo.int/ ipstats/en/>. Acesso em: abr. 2011. 